\title{
ISOLATION AND CHARACTERISATION OF GIBBERELLIN 2-OXIDASE 6 GENE FROM OIL PALM (Elaeis guineensis Jacq.)
}

\section{ZATTY SYAMIMI ADURA, M S*; NURNIWALIS, A W* and ZUBAIDAH, R*}

\begin{abstract}
To increase our understanding on the role of Gibberellin (GA) metabolism in oil palm (Elaeis guineensis), a gene encoding enzyme in GA catabolic pathways was identified and isolated. The oligonucleotide primers were constructed and used to amplify the EgGA2ox6 gene from oil palm. The sequence analysis of EgGA2ox6 gene provided a complete open reading frame (ORF) of 1014 bp which encodes 337 deduced amino acid residues. Homology sequence analysis has shown a 50\%-70\% sequence similarity to GA from other plant species. Based on this sequence motif analysis, the EgGA2ox6 is classified into $C_{19}-G A 20 x$ group. Expression studies on 13 different oil palm tissues showed that the highest expression profile of the gene was observed in the mesocarp tissue. Further expression analysis was conducted on the development stages of mesocarp using quantitative real-time polymerase chain reaction ( $q R T-P C R$ ) showed that the gene was predominantly expressed in the early stages of mesocarp development at four weeks after anthesis (WAA). Then, the expression of EgGA2ox6 gene was gradually reduced as the fruit ripened. This preliminary study provides valuable resources to further elucidate the roles of GA2ox6 gene during oil palm fruit development.
\end{abstract}

Keywords: expression, GA 2-oxidase, isolation, mesocarp, oil palm.

Received: 10 February 2020; Accepted: 9 July 2020; Published online: 22 September 2020.

\section{INTRODUCTION}

Oil palm is a commercially important crop in the world with increasing production over the years. Malaysia is one of the palm oil producing countries that accounts for over one-third of world palm oil and fat production (Zulkifli et al., 2017). Because of that, Malaysia plays a role in achieving the growing global need for oil and fat sustainably.

Gibberellin, also known as gibberellic acid (GA), is a phytohormone that plays essential roles in plant growth, in both vegetative and reproductive phases such as seed germination, stem elongation, leaf expansion, flowering and fruit development

Malaysian Palm Oil Board,

6 Persiaran Institusi, Bandar Baru Bangi,

43000 Kajang, Selangor, Malaysia.

E-mail: bai@mpob.gov.my
(Hedden and Thomas, 2012; Daviere and Archard, 2013; Gupta and Chakrabarty, 2013; Rahman et al., 2016). Accordingly, treatments with GA in agronomic sector have become a common practice for improvement of crop performance. Bioactive GA is among the most widely used as plant growth regulators (PGR) in order to 'fine-tuning' the crop plant to its particular growth condition (Rademacher, 2016). For example, in temperate fruit trees, PGR of $\mathrm{GA}_{3}$ are used to stimulate the growth of parthenocarpic pears as well as for fruit set (Quinet and Jacquemart, 2015) and also improve fruit quality of cherries (Zhang and Whiting, 2013) and citrus species (Fidelibus et al., 2002). Besides, bioactive $\mathrm{GA}_{4 / 7}$ is often used by apple growers to improve the fruit quality (Watanabe et al., 2008). With the successive application of chemical regulator to the crop plantation, exogenous application of $\mathrm{GA}_{3}$ to oil palm had also been studied and gave the effect 
to fruit width, fruit length, fruit weight and bunch weight (Sangwiroonthon et al., 2017). However, the mechanism by which these effects are achieved has to be explored.

As alternative approach to the application of chemical regulator of GA would be genetic manipulation of their GA biosynthesis. The GA biosynthetic pathway has long been studied and most of the biosynthetic gene encoding enzymes have been identified and characterised in many plant species. Previous studies revealed that the level of bioactive GA is regulated by gene encoding enzymes from both biosynthetic and catabolic pathways (Olszewski et al., 2002; Du et al., 2015; Pan et al., 2017). GA 20-oxidase and GA 3 -oxidase are important regulating enzymes in the biosynthetic pathway (Yamaguchi, 2008; Hedden and Thomas, 2012; Salazar-Cerezo et al., 2018). The regulation of this catabolic pathway involves GA 2-oxidase (GA2ox), a $2 \beta$-hydroxylation enzyme that hydroxylates $\mathrm{C}-2 \beta$ of bioactive GA to produce a biologically inactive form (Martin et al., 1999; Thomas et al., 1999; Rieu et al., 2008; Shan et al., 2014).

Catabolism of GA maintains the level of endogenous GA through the reduction of bioactive GA, which is important in the regulation of plant growth. The genes encoding enzyme GA2ox were first identified by screening cDNA expression for 23-hydroxylase activity (Martin et al., 1999; Thomas et al., 1999). Early characterisation of GA2ox revealed that the enzyme hydroxylates the $\mathrm{C}-2$ of active $\mathrm{C}_{19}$-GA $\left(\mathrm{GA}_{1}\right.$ and $\left.\mathrm{GA}_{4}\right)$ and its precursors $\left(\mathrm{GA}_{9}\right.$ and $\left.\mathrm{GA}_{20}\right)$ to produce inactive forms of GA $\left(\mathrm{GA}_{8}, \mathrm{GA}_{34}, \mathrm{GA}_{29}\right.$, and $\left.\mathrm{GA}_{51}\right)$ (Lange et al., 2013; Chen et al., 2016). Later, the gene encoding GA2oxs was able to catabolise the $\mathrm{C}_{20}-\mathrm{GA}$ precursors $\left(\mathrm{GA}_{12}\right.$ and $\left.\mathrm{GA}_{53}\right)$ and produce inactive GA $\left(\mathrm{GA}_{110}\right.$ and $\left.\mathrm{GA}_{97}\right)$ (Schomburg et al., 2003; Huang et al., 2010; Chen et al., 2016; Lange et al., 2013).

GA2ox genes have been isolated from various plant species such as runner bean (Phaeseolus coccineus) (Dijkstra et al., 2008), Arabidopsis thaliana (Thomas et al., 1999), garden pea (Pisum sativum) (Lester et al., 1999; Martin et al., 1999) and rice (Oryza sativa) (Sakamoto et al., 2001). The physiological functions of these genes have been determined, where overexpression of GA2ox genes in plants can cause dwarf phenotype (Lo et al., 2008; Hu et al., 2017) and in some cases, affect their reproductive development (Sakamoto et al., 2001; Busov et al., 2003; Zhou et al., 2012; Huet al., 2017). Conversely, loss-of-function of these genes can result in a tall and slender phenotype (Martin et al., 1999; Rieu et al., 2008).

Considering the role of catabolic GA enzyme in response to the level of bioactive GA in plant biosynthetic pathways, we seek to identify gibberellin oxidase family in oil palm. In this study, we conducted the isolation and characterisation of a GA2ox gene from oil palm (EgGA2ox6). We also examined the expression profile of the EgGA2ox6 gene in vegetative and reproductive tissues of oil palm using reverse transcription-polymerase chain reaction (PCR) and real-time quantitative PCR (RTPCR) and quantitative real-time (qRT-PCR). This result provides us some important information about the localisation function of EgGA2ox6 gene in regulating GA catabolism pathway in oil palm and also gives an idea to further investigate the functional role of the gene.

\section{METHODOLOGY}

\section{Plant Material}

Oil palm tissues (Elaeis guineensis) were collected from several one-year-old of Deli Dura x AVROS pisifera (DxP) clonal oil palm seedlings. The oil palm seedlings were harvested and the tissues were categorised accordingly: shoot primordia, young leaf, young node, young internode, young root, mature leaf, mature node, mature internode, mature root, basal stem and cabbage. As for the sampling of the mesocarp tissue, oil palm fruits were collected at 4, 8, 12, 16, 20 and 22 weeks after anthesis (WAA). Kernel tissues were collected from fruits at 16 WAA. All tissues were cut into small sizes, flash frozen in liquid nitrogen and stored at $-80^{\circ} \mathrm{C}$.

\section{Isolation of Total RNA from Oil Palm Tissues and cDNA Synthesis}

To extract total ribonucleic acid (RNA) from oil palm, $100 \mathrm{mg}$ of oil palm tissues was ground to powder in liquid nitrogen. Total RNA extraction was then carried out using innuPREP RNA mini kits (Analytik Jena, Germany) as per the manufacturer's protocol. The total RNA obtained was quantified by using NanoDrop spectrophotometer (ND-1000, ThermoScientific, USA). The quality and integrity of RNA were determined using Fragment Analyser (Advanced Analytical Technologies Inc., Ames, IA, USA). Then oligo (dT) primer and Superscript ${ }^{\mathrm{TM}}$ III Reverse Transcriptase (Invitrogen, USA) were used to reverse transcribe the total RNA, according to the manufacturer's protocol. After that, the synthesised cDNA was used as a template for RTPCR amplification. For the amplification of $5^{\prime}$ - and 3'- ends of cDNA, rapid amplification of cDNA ends (RACE) (Clontech, USA) were used to obtain full-length cDNA sequence.

\section{EgGA2ox6 Gene Isolation}

The sequence consensus available of GA2ox genes were used to search for putative oil palm GA-oxidase sequences available in Genomsawit 
databases (http:/ /genomsawit.mpob.gov.my). From the sequence obtained, a few sets of primers were designed using Primer-Blast (https:/ / www.ncbi. nlm.nih.gov/tools/primer-blast/) that covered the GA-preferred motifs in the sequence. RT-PCR was performed using the Q5® High-Fidelity DNA Polymerase (NEB, USA) and specific primers (Table 1) according to the manufacturer's instructions. The cDNA generated from leaf tissue was used as the PCR template for preliminary screening of the target gene from oil palm. The RT-PCR reaction was carried out with initial denaturation step at $98^{\circ} \mathrm{C}$ for $30 \mathrm{~s}$, followed by 30 cycles of $98^{\circ} \mathrm{C}$ for $10 \mathrm{~s}, 56^{\circ} \mathrm{C}$ for $20 \mathrm{~s}$ and $72^{\circ} \mathrm{C}$ for $30 \mathrm{~s}$ and final extension at $72^{\circ} \mathrm{C}$ for $2 \mathrm{~min}$. Beta-actin ( $\beta$-actin) gene was used as an internal control that required $56^{\circ} \mathrm{C}$ of annealing temperature. The PCR fragment was observed on $1 \%(\mathrm{w} / \mathrm{v})$ agarose. The gel was viewed using $\mathrm{G}$ : Box Syngene Images Analysers (Syngene, United Kingdom) and the targeted band was excised and purified using Gel Extraction Kit (QIAGEN, USA) and finally inserted into pMiniT vector (NEB,USA) prior to DNA sequencing. To obtain full-length cDNA sequence, amplification of $5^{\prime}$ and $3^{\prime}$-ends of cDNA was performed using SMART ${ }^{\mathrm{TM}}$ RACE cDNA amplification Kit (Clontech, USA) together with the sense and anti-sense oligonucleotide primers (Table 1). PCR conditions for RACE were as follows: 40 cycles of $94^{\circ} \mathrm{C}$ for $30 \mathrm{~s} ; 68^{\circ} \mathrm{C}$ for $30 \mathrm{~s}$ and $72^{\circ} \mathrm{C}$ for $3 \mathrm{~min}$. The resulting PCR products were gel purified and cloned into a plasmid vector prior to sequencing.

\section{Gene Analysis of EgGA2ox6}

Analysis of EgGA2ox6 gene sequence was carried out using in-silico approaches. The gene sequence obtained from the amplification of EgGA2ox6 was analysed and translated using ExPASy programme (http://www.expasy.org/translate/) to generate a deduced amino acid sequence. The amino acid sequence characterisation was predicted using the ProtParam tool (https://web.expasy. org/protparam/). Subcellular localisation of the protein was predicted using WoLF PSORT (https: / / www.genscript.com/wolf-psort.html) and TargetP tools (www.cbs.dtu.dk/services/ TargetP/). The protein family of the gene was analysed using pfam database. The EgGA2ox6 deduced amino acid residues were then submitted for NCBI BLASTP (www.ncbi.nlm.nih.gov) search to look for sequence similarities from other species. The genomic structure of EgGA2ox6 was constructed using GeneWise (https://www.ebi. ac.uk/Tools/psa/genewise/). Multiple sequence alignment (MSA) was generated using Clustal Omega program (https://www.ebi.ac.uk/Tools/ $\mathrm{msa} /$ clustalo/) for selected GA2oxs. The motif sequences and protein domain identification were performed using MEME Suite tools (meme-suite. org). The phylogenetic tree of protein sequences was constructed using MEGA 6 (Tamura et al., 2007) through Maximum Likelihood method with 1000 bootstrap replicates.

\section{Expression Profile of EgGA2ox6}

Expression analysis using semi-quantitative RT-PCR. For gene expression analysis, semiquantitative PCR was carried out using synthesised cDNA of young and mature vegetative and also reproductive tissues. The tissues used were as follows: shoot primordia, young leaf, young node, young internode, young root, mature leaf, mature node, mature internode, mature root, basal stem, cabbage, mesocarp and kernel. Expression levels of

TABLE 1. LIST OF PRIMER SEQUENCES

\begin{tabular}{|c|c|}
\hline Primer & Primer sequence \\
\hline \multicolumn{2}{|l|}{ Gene amplification } \\
\hline \multirow{2}{*}{$\begin{array}{l}\text { 1. EgGA2ox (Forward) } \\
\text { EgGA2ox (Reverse) }\end{array}$} & 5'-CATGGTGATCGCTTCAGGTCACTC-3' \\
\hline & 5'-CATCTGCACGGAAGAGATCAAGG-3' \\
\hline \multirow{2}{*}{$\begin{array}{l}\text { 2. EgGA2ox (Forward) } \\
\text { EgGA2ox (Reverse) }\end{array}$} & 5'-CATCATCCGTTCTCTCАСТСТTTTCACCC-3' \\
\hline & 5'-GCATGCTCTTCCСТCTTTGTAATAACCCTG-3' \\
\hline \multicolumn{2}{|l|}{ RACE } \\
\hline $5^{\prime}$ EgGA2ox & 5'-GCAGCGAGGCATTTGGGGTGTGGTC-3' \\
\hline 3' EgGA2ox & 5'-GACCACACCCCAAATGCCTCGCTGC-3' \\
\hline \multicolumn{2}{|l|}{ qRT-PCR } \\
\hline EgGA2ox (Forward) & 5'-GTCGACATCGTCTCACGGAT-3' \\
\hline EgGA2ox (Reverse) & 5'-ACACCAGCTTGTTGGGAGAC-3'. \\
\hline \multicolumn{2}{|l|}{ Control } \\
\hline B-actin (Forward) & 5'-TGAGAGGGAAATCGTGCGTG-3' \\
\hline B-actin (Reverse) & 5'-TGCTTGCTGATCCACATCTGC-3' \\
\hline
\end{tabular}


the gene in respective tissues were gauged by the intensity of the amplified products showed in the agarose gel. Then, the gene expression was further analysed by quantifying the expression in detail for each of the developmental stage.

Expression analysis using real-time quantitative (qRT-PCR). SYBR ${ }^{\circledR}$ Green Supermix (BioRad, USA) was used for qRT-PCR. PCR reactions were performed following this protocol: initial deactivation of $95^{\circ} \mathrm{C}$ for $30 \mathrm{~s}$ followed by 40 cycles of $95^{\circ} \mathrm{C}$ for $5 \mathrm{~s}$ and $60^{\circ} \mathrm{C}$ for $30 \mathrm{~s}$. After amplification, the temperature starting from $65^{\circ} \mathrm{C}$ was gradually increased by $0.5^{\circ} \mathrm{C}$ every $5 \mathrm{~s}$ until $95^{\circ} \mathrm{C}$. Each run was completed with a dissociation stage to generate melt curves for amplification specificity evaluation. The qPCR was conducted using CFX96 ${ }^{\mathrm{TM}}$ RT-PCR Detection System (BioRad, USA). All qPCR data is a mean of three sample replicates. The cDNAs from mesocarp at 4, 8, 12, 16, 20 and 22 WAA were used as templates for qRT-PCR. Cyclophilin 2 (Cyp2) and Gibberellin-responsive protein 2 (GRAS) were used as reference genes to normalise the expression gene. Both of the reference genes were detected as suitable candidate genes for normalisation of the gene expression under oil palm seedlings and mesocarp tissue (Wong et al., 2014; Yeap et al., 2014; Halim et al., 2019). The primers used for qRT-PCR are listed in Table 1. The relative normalised expression level was calculated according to the method of $2^{-\Delta \Delta C q}$ (Livak and Schmittgen, 2001).

\section{RESULTS AND DISCUSSION}

\section{RNA Quality and Integrity Analysis}

Prior to single-stranded cDNA synthesis, the purity and quality of intact total RNA are critical elements for the overall success of RNA-based analysis (Imbeaud et al., 2005; Leige and Pfaffl, 2006; Azizi et al., 2017). The extracted total RNA showed a purity level ranging from 1.8-2.0 $\left(\mathrm{A}_{260 / 280}\right.$ and $\left.A_{260 / 230}\right)$ with yield concentration of $100-500$ ng $\mu \mathrm{l}^{-1}$. The integrity of total RNA was checked using Fragment Analyser (Advanced Analytical Technologies, Inc., Ames, IA, USA) which resulted the RNA Quality Number (RQN) of the samples ranging between 8.0-9.2. A higher RQN value indicates a good quality of RNA sample. The RQN value of 1.0 is indicative of RNA degradation, whereas the value of up to 10.0 suggests that the RNA is fully intact (Wong and Pang, 2013). The RQN value is a proprietary algorithm linked to the Fragment Analyser system that has been shown to correlate with RNA Integrity Number (RIN), values as a quality metric indicator (Wong and Pang, 2013; Escobar and Hunt, 2017; Sanchez et al., 2017). RNA quality values below 7.0 indicate high variation and loss of statistical significance for gene expression when analysed by qRT-PCR (Jahn et al., 2008). Furthermore, the RNA value of 7.0 or higher is a recommended range for experiment to proceed to cDNA synthesis and SMARTer RACE experiments. The digital gel image and electropherogram provided by PROsize (Data analysis software for Fragment Analyser) for the oil palm tissues showed clear bands of $25 S$ and $18 S$ rRNAs with no smearing along the migration of RNA sample (Figures $1 a$ and $1 b)$. Moreover, the measured electropherogram signals showed clear peaks of $25 \mathrm{~S}$ and $18 \mathrm{~S}$ rRNAs without any spike or abnormal fluctuation of the baseline. This indicated that the RNA sample was intact and in good quality.

\section{Isolation and Structural Characterisation of EgGA20x6 cDNA}

Oil palm orthologous gene analysis showed that there were several GA oxidase genes identified in oil palm genome. Out of many genes identified, one of them was selected to isolate and further analyse its expression. The putative gene was available in NCBI database with accession number of XM_010939891.3 and it LOC ID was LOC105057308. This gene shows similarity with two sets of gene prediction of Pheonix dactylifera 2-beta-dioxygenase 2-like, with LOC ID were LOC103709678 and LOC103701020 with $89.93 \%$ and $88.86 \%$ similarity, respectively (data not shown). Using the predicted GA2ox gene, the primers were generated covering the important motif sequence of the gene. Isolation of partial $E g G A 20 x 6$ gene was performed using PCR amplification and the result showed the gene was of the expected size (Figure 2). Sequence analysis of the PCR product indicated that this fragment encodes a part of the GA2ox gene family. Results obtained from the RACE experiments presented a full-length cDNA including the $5^{\prime}$ and $3^{\prime}$ - untranslated regions (UTR) of the gene. The full-length cDNA sequence of EgGA20x6 was $1287 \mathrm{bp}$ including a 5' and 3' UTR of $106 \mathrm{bp}$ and $167 \mathrm{bp}$ length, respectively. The open reading frame (ORF) of the gene was 1014 $\mathrm{bp}$, encoding a deduced amino acid sequence of 337 residues. The predicted molecular mass of the protein was $37 \mathrm{kDa}$ with a theoretical isoelectric point (pI) at 5.58. The EgGA20x6 gene was predicted to be located in the cytoplasm and nucleus, which is related to their functional location (Hedden and Thomas, 2000; Huang et al., 2010).

Investigation of the structural features of $E g G A 20 x 6$ gene was determined by using GeneWise tool where it presented that the EgGA2ox6 gene consisted of two introns and three exons at chromosome 14. The sizes of exon I, followed by intron I, exon II, intron II and exon III were $382 \mathrm{bp}$, $1546 \mathrm{bp}, 357 \mathrm{bp}, 676 \mathrm{bp}$ and $269 \mathrm{bp}$, respectively. The gene structure was constructed and illustrated as in 


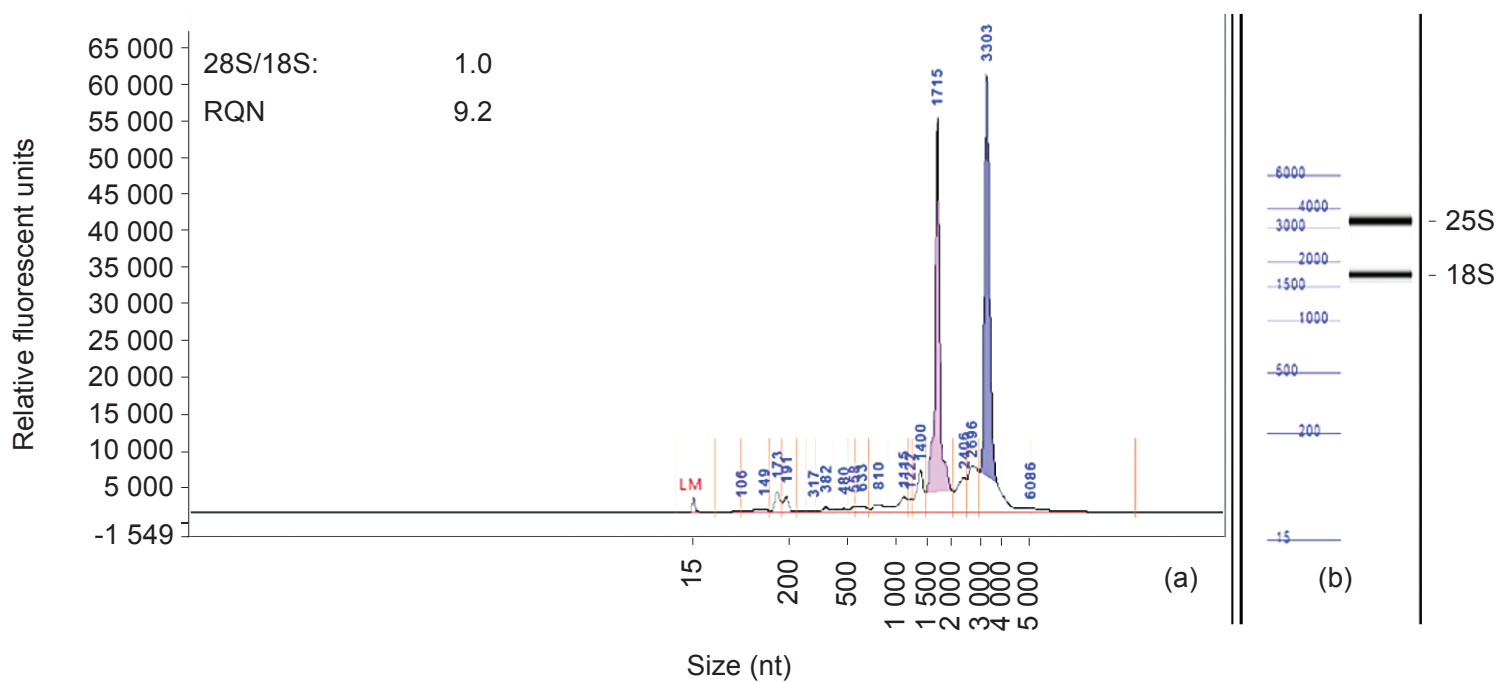

Figure 1. Electropherogram of total RNA generated from fragment analyser. (a) The blue peak corresponds to $25 S \mathrm{rRNA}$ and red peak corresponds to $18 S$ rRNA. (b) The migration of $25 S$ and $18 S r R N A$ of total RNA by using fragment analyser.

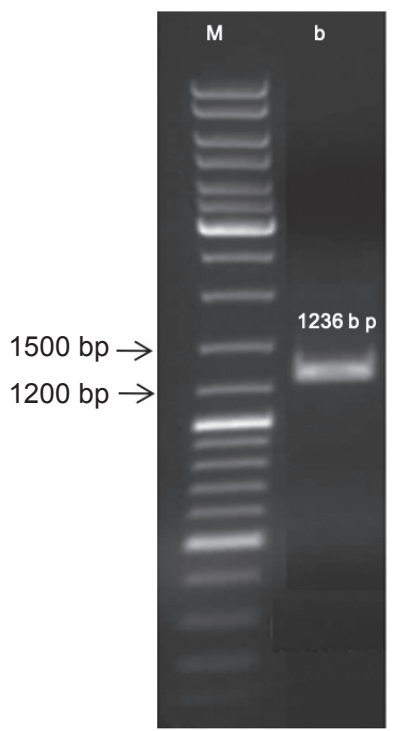

Figure 2. PCR amplification of EgGA2ox6. (M) GeneRuler ${ }^{\mathrm{TM}}$ Ladder Mix, (b) EgGA2ox amplified gene present in oil palm tissue. PCR amplification was performed using a specific primer to isolate GA2oxidase gene from oil palm leaf.

Figure 3. Comparative gene structure among GAox gene sequences showed that most of the GAox subfamilies have similar exon-intron numbers unless the gene undergo divergence evolutionary mechanism (Han and Zhu, 2011).

Analysis of the protein sequence of EgGA2ox6 demonstrated that the protein was categorised under the DIOX_N family which contains a conserved domain of 2-oxoglutarate (2OG) and $\mathrm{Fe}$ (II)-dependent oxygenase superfamily (2-ODD). In general, this group of oxidative enzymes is part of the plant growth regulator

\section{EgGA2ox6}

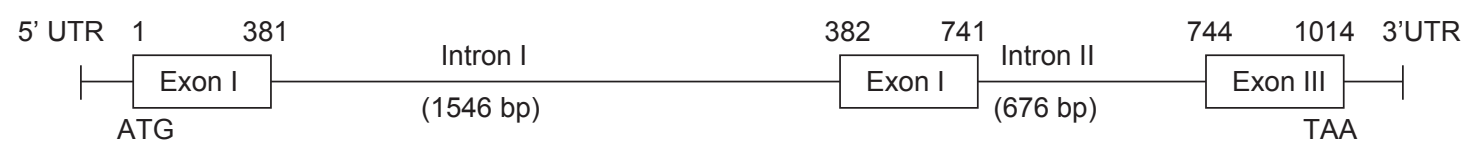

Figure 3. Schematic representation of the gene structure of EgGA2ox6. Numbers presented above the exon I, intron I, exon II, intron II and exon III indicate the position of bases in the coding sequence starting from ATG. Numbers below the exons and introns in parentheses indicate the size of each intron. 
activation and catabolism as they are responsible for several structural modifications (Yamaguchi 2008; Pan et al., 2017). The conserved domain of 2-ODDs in EgGA2ox6 gene is likely to function similar to other GA2ox which is to catalyse the hydroxylation of active GA to inactive form (Lee and Zeevaart, 2005).

BLAST analysis of the deduced amino acid sequence with that of other available protein sequences in the database demonstrated that the deduced protein sequence shares sequence identity ranging from $50 \%-70 \%$ which is closely related to other GA2ox orthologues (Table 2). Alignment of the EgGA2ox6 amino acid sequences with other GA2oxs highlighted a number of conserved motif and structural similarity among them. The genes shared common conserved motifs similar to other GA-oxidases that is a putative 2-oxoglutaratebinding (2-OG) and iron-binding sites (2-ODD). The site of 2-OG was located at Arg-269 and Ser271 in EgGA2ox6 sequence. For 2-ODD, the catalytic core consisted of iron atom chelated in an active site assisted by two His (His-198; His-259) and an Asp-200 in sequence composition of HXD/EXnH (Figure 4). The catalytic triad binds Fe(II) as a cofactor to assist in the catalysis of their substrates (Kawai et al., 2014). In addition, the partial NXYPXC sequence of 2-ODD was also conserved in the sequence of EgGA20x6 as in other GA2oxs (Xu et al., 1995; Xu et al., 2002; Pan et al., 2017). The sequence was located at Asn177-His177-Tyr178Pro179-Pro180-Trp181 in the deduced protein sequence. This putative sequence was proposed to be involved in the binding of a common cosubstrate (2-oxoglutaric acid) (Xu et al., 1995; Xu et al., 2002; Pan et al., 2017). Furthermore, the sequence motif of GYGXnNGDXnEYL was also presented in the sequence, as it was highly conserved among $\mathrm{C}_{19}$-GA2oxs gene. Thus, it proved that the EgGA2ox6 is classified under $\mathrm{C}_{19}$-GA2oxs group. This conserved region was suspected to be involved in $\mathrm{C}-2$ hydroxylation of active $\mathrm{C}_{19}$-GA2oxs (Huang et al., 2015; Chen et al., 2016). Although the overall sequence similarity of the GA2ox genes is quite low, the amino acid sequence at its catalytic site is well conserved closely to the carboxyl-terminal of the sequence.

\section{Phylogenetic Tree Analysis of EgGA2ox6}

To classify the EgGA2ox6 sequence among various GA2oxs, a phylogenetic tree was constructed and 15 discrete motifs were identified. From the phylogenetic analysis, the GA2oxs were divided into two main classes based on sequence conservation (Figure 5). The first main lineage consisted of GA2ox gene from six different plant species: Manihot esculenta (MeGA2ox), Hevea brasiliensis (HbGA2ox), Jatropha curcas (JcGA2ox), Populus tomentosa (PtGA2ox), Purnuspersia (PpGA2ox) and Durio persica (DpGA2ox). Meanwhile, the second lineage was formed by GA2ox from Ananas comosus (AcGA2ox), Elaeis guineensis (EgGA2ox6), Asparagus officinalis (AoGA2ox), Dendrium catenatum (DcGA2ox) and Phalaenopsis equestris (PeGA2ox). EgGA2ox6 was closely related to AcGA2ox (Ananas comosus) as they shared the same sub-lineage. Moreover, AcGA2ox shared a similar genomic structure as EgGA2ox6 since the length and number of exons / introns were similar. The similarity of both genes might reflect by the shared functional conservative of the genes (Huang et al., 2015).

Essentially, all GA2ox proteins shared similar conserved motifs except for motif 15 . Motif 2 was located in the DIOX_N domain, while 2OGFeII_Oxy domain included motif 1 , motif 7 and motif 8 . Motif 15 was shared only by four GA2ox - Manihot esculenta (MeGA2ox), Hevea brasiliensis (HbGA2ox), Jatropha curcas (JcGA2ox) and Populus tomentosa (PtGA2ox). Motif 15 may indicate a conserved functional role shared by these four

TABLE 2. BLAST RESULTS OF EgGA2ox6

\begin{tabular}{|c|c|c|c|c|c|c|c|}
\hline No. & Species & $\begin{array}{l}\text { Max. } \\
\text { score }\end{array}$ & $\begin{array}{l}\text { Total } \\
\text { score }\end{array}$ & $\begin{array}{c}\text { Query } \\
\text { cover }(\%)\end{array}$ & E-value & $\begin{array}{c}\text { Identity } \\
(\%)\end{array}$ & Accession No. \\
\hline 1 & Asparagus officinalis & 441 & 441 & 99 & $2 \mathrm{e}-152$ & 61 & XP020254363.1 \\
\hline 2 & Ananas comosus & 434 & 434 & 98 & $1 \mathrm{e}-149$ & 66 & ONK78771 \\
\hline 3 & Durio zibethinus & 412 & 412 & 98 & $3 e-141$ & 59 & OAY7773171 \\
\hline 4 & Jatropha curcas & 409 & 409 & 96 & $3 e-140$ & 60 & ХР012082949.1 \\
\hline 5 & Dendrobium catenatum & 410 & 410 & 98 & $6 e-140$ & 57 & XР020701220.1 \\
\hline 6 & Manihot esculenta & 405 & 405 & 96 & $1 e-138$ & 60 & XP0216232581 \\
\hline 7 & Phalaenopsis equestris & 403 & 403 & 93 & $9 e-130$ & 60 & XP020582243.1 \\
\hline 8 & Prunus persis & 394 & 394 & 97 & $6 e-134$ & 57 & XP0072214871.1 \\
\hline 9 & Populus tomentosa & 392 & 392 & 96 & $2 e-132$ & 57 & AGW52151.1 \\
\hline 10 & Hevea brasiliensis & 391 & 391 & 96 & $6 e-133$ & 59 & XР021639858.1 \\
\hline
\end{tabular}



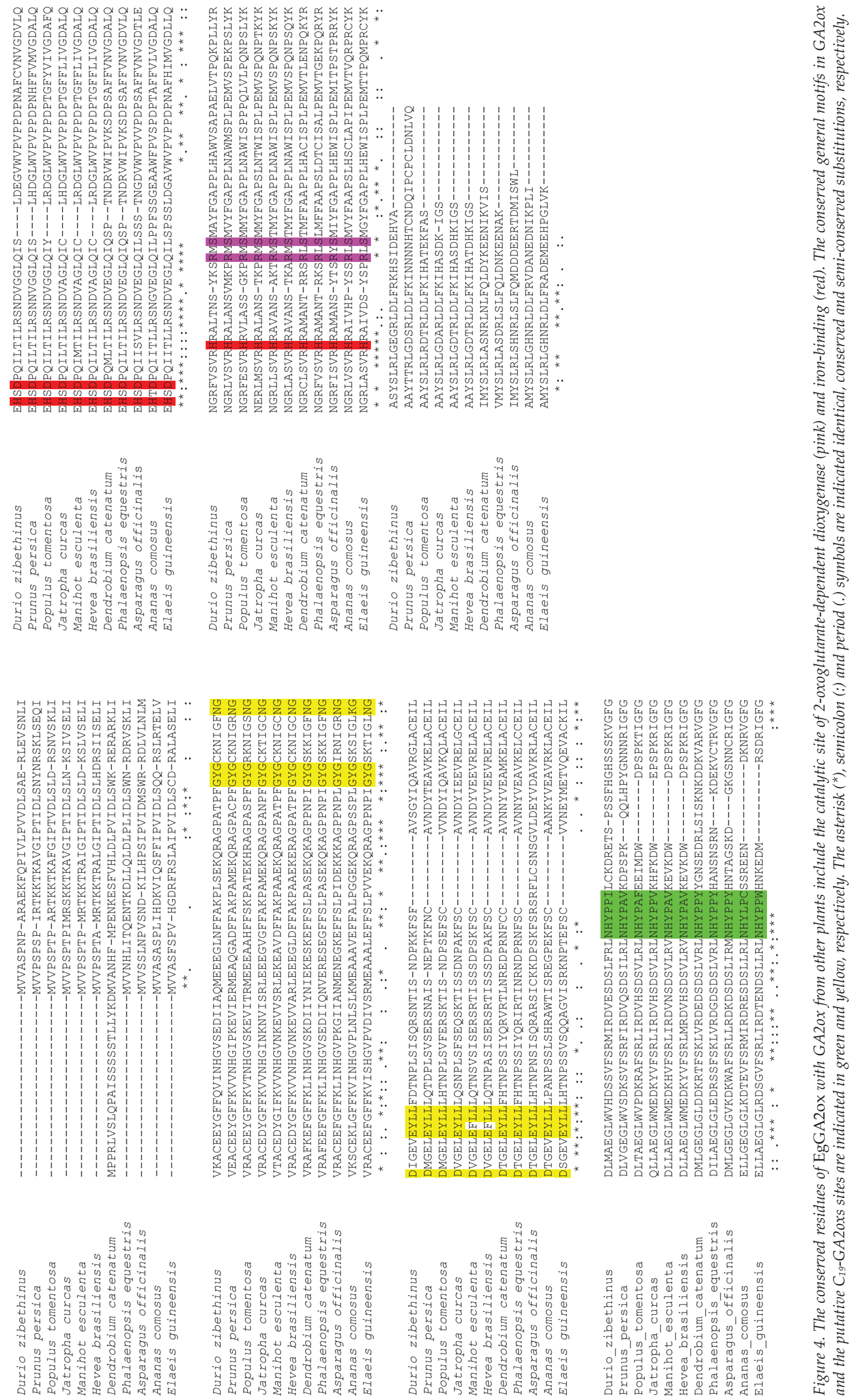
plant species. It may be due to the evolutionary conservation of protein sequence among GA2ox family members.

\section{Expression Profile of EgGA2ox6 Genes in Different Oil Palm Tissues}

The expression of EgGA2ox6 gene was analysed in 13 different oil palm tissue samples which were spear leaf, matured leaf, young node, matured node, young internode, matured internode, white root, brown root, shoot primordia, cabbage, basal stem, mesocarp and kernel. The expression level of EgGA2ox6 was indicated by the intensity of the amplified band in the agarose gel (Figure 6). EgGA2ox6 transcript was strongly expressed in mesocarp tissue and scarcely expressed in mature leaf and mature internode. Other than this, no expression was observed in other tested tissues. From the expression results obtained, EgGA20x6 exhibited a tissue-specific expression in mesocarp, though there were traces of gene expression in mature leaf and internode. The expression of EgGA20x6 in mesocarp was analysed in detail, starting from early developmental stages of mesocarp development until the fruit ripened.

\section{The Expression Pattern of EgGA2ox6 Gene during Mesocarp Development}

Melt curve was performed to examine the specificity of the primer to amplify the target gene. The melt curve profiles clearly demonstrated that the qPCR assays produced single and specific product by producing a single peak for each sample. Later, the relative normalised expression of EgGA20x6 in every stage of mesocarp tissues were conducted and analysed. The relative quantity of gene in each tissue was normalised to the relative quantity of the reference gene used. Throughout the developmental period of the mesocarp tissues, the EgGA20x6 transcription was predominantly expressed in 4 WAA of the mesocarp tissues. The expression was shown to decrease about twothirds in Week 8, and slightly increased in Week 12 and then decreased until Week 22 (Figure 7). Oil palm fruit takes 20-22 weeks to ripen from the anthesis stage by completing its development, maturation and ripening stage. Initially, a fruit set represents a very early fruit development stage which undertakes cell division and expansion along with initial increase in fruit mass and size. These activities are coordinated by the concerted action of the many phytohormones including GA. High expression of EgGA2ox6 gene indicates that the GA deactivating gene is important for establishing suitable GA levels during early fruit set development. There were reports where the levels of bioactive $\mathrm{GA}_{3}$ and $\mathrm{GA}_{4}$ were intricated during oil palm mesocarp development (Teh et al., 2014). Both bioactive hormones presented a clear opposite trend throughout fruit ripening as $\mathrm{GA}_{3}$ appeared to be higher in Week 12 and decreased throughout the ripening process. Meanwhile, expression of $\mathrm{GA}_{4}$ was said to increase throughout fruit ripening (Teh et al., 2014; Transberger et al., 2011). The expression pattern of EgGA20x6 throughout fruit development was thought to be coordinated with the expression level of bioactive $\mathrm{GA}_{4}$ as the EgGA2ox6 may be involved in its catabolic pathway. Throughout the maturation stages, the mesocarp fruit mass was increased and reached the competence to ripen about 16-18 WAA. As the ripening progressed, the expression level of EgGA2ox6 was generally low possibly due to a major switch in relative hormone levels of the fruit ripening. Low expression of EgGA20x6 at stages of ripening was concomitant with the high accumulation of $\mathrm{GA}_{4}$ at later stages of fruit ripening. In particular, $\mathrm{GA}_{4}$ was said to be an important bioactive hormone in oil palm fruit ripening (Teh et al., 2014) as well as in cucumber (Nakayama et al., 1991) and Arabidopsis (Cowling et al., 1998). Involvement of this catabolic enzyme was previously shown in plum fruit development (Prunus salicina L.) (El-Sharkawy et al., 2012) where the PslGA2ox transcript was expressed mainly throughout immature stages before ripening. The same goes to tomato fruit, where the SlGA20x1 shows high expression in the fruit at the immature green stage but is barely expressed in the red ripening stage (Chen et al., 2016; Serrani et al., 2007).

Studies on the relationship between GA and fruit development was conducted by Chen et al. (2016) and Li et al. (2019). The expression of fruitspecific SIGA2ox1 in tomato causes reduction of GA level in fruit tissues that leads to early ripening in transgenic tomato. The study also found out that the injection of GA biosynthesis inhibitor, prohexadione-Ca into mature-green fruits resulted in an early fruit ripening which is consistent with the previous observation in transgenic tomato fruit. This was a proof of the regulating role of the GA in fruit ripening. In addition, low level of GA concentration in fruit also accelerates the expression of ripening regulator, and finally triggers the expression of ethylene biosynthetic genes for early ripening compared to normal fruit ripening ( $\mathrm{Li}$ et al., 2019). There was also a report on the relationship between $A c G A 2 o x$ and its physiological disorder of the harvested pineapple (Ananas comosus) which is a monocot plant. This study has shown that the expression of AcGA2ox resulted in reduced levels of bioactives GA, which triggered response in regulating of transcriptional of $A c P P O$ (pineapple polyphenol oxidase) gene. $A c P P O$ gene was upregulated in response to the level of $\mathrm{GA}_{4 / 7}$. By increasing the expression of 

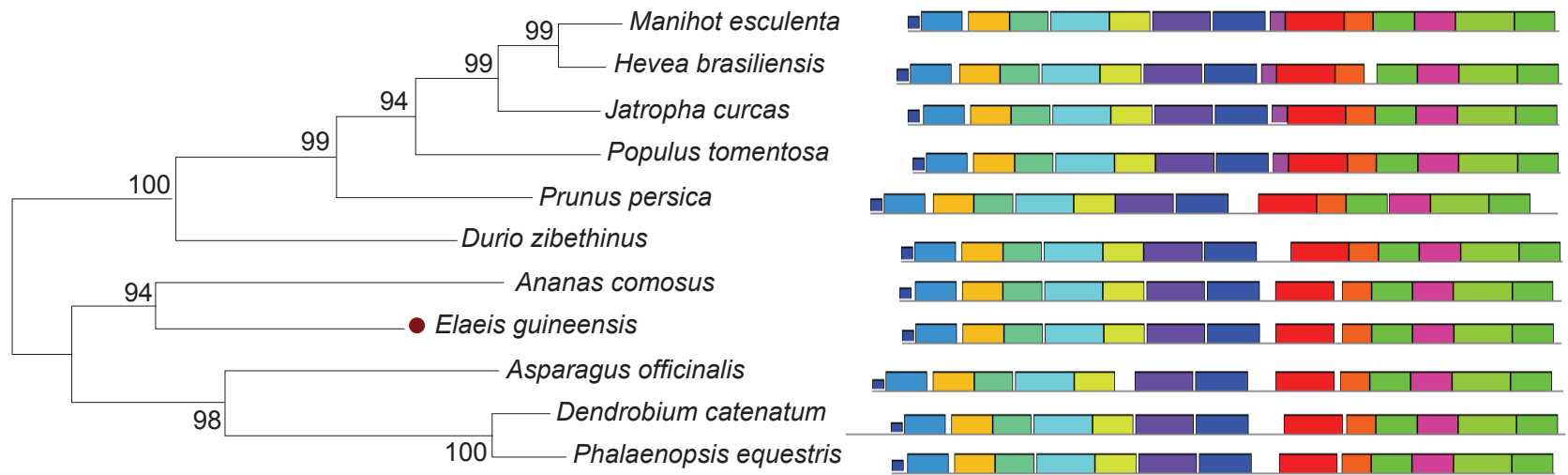

0.1

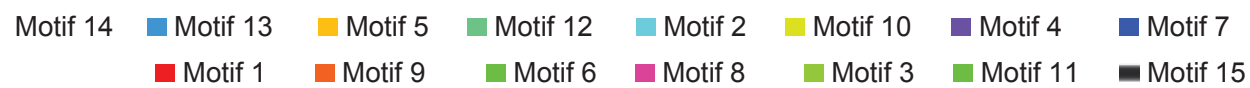

Figure 5. Phylogenetic tree and conserved motif analysis of EgGA2ox protein sequences among different plant species. The motifs were identified using MEME software and a phylogenetic tree was constructed using MEGA6 software. Fifteen motifs were identified and differentiated as shown by coloured boxes, including the distribution of each motif along the sequences corresponding to their positions.

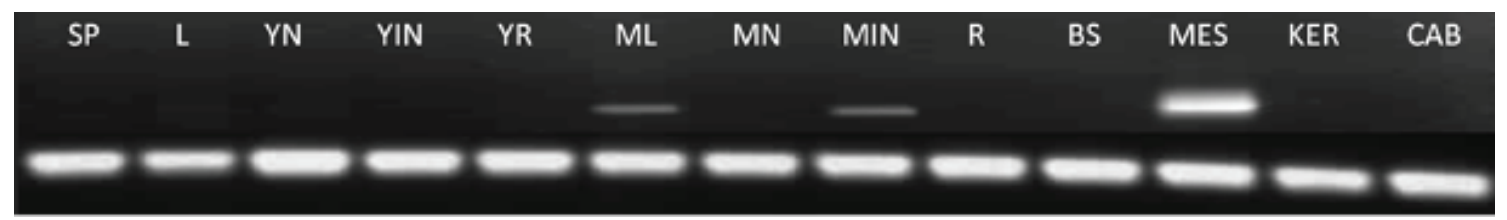

EgGA2ox6

Actin

Figure 6. Expression profile of EgGA2ox6 in different tissues of oil palm. The oil palm tissue samples included: SP, shoot primordia; $L$, leaf; $Y N$, young node; YIN, young internode; YR, young root; ML, mature leaf; MN, mature node; MIN, mature internode; R, root; BS, basal stem; MES, mesocarp; KER, kernel; CAB, cabbage. Actin represents control.

AcGA2ox, led to a decrease transcription level of $A c P P O$, which then resulted in a decreased oxidation of phenolic compound that caused internal browning of pineapple (Zhang et al., 2016). Physical damages on fruits affect the quality and lead to a severe loss of their commercial value.

We envisage that EgGA2ox6 as one of the GA catabolic enzymes that could metabolise the reduction of GA level in oil palm mesocarp. In normal oil palm mesocarp development, different accumulation of EgGA2ox6 throughout mesocarp development showed the importance of its catabolic enzyme in stabilising GA level in oil palm fruit. Modulating the expression of the enzyme could cause changes in phenological characteristic of reproductive growth, as well as substantial disorder that could give significant modification in fruit cycle.

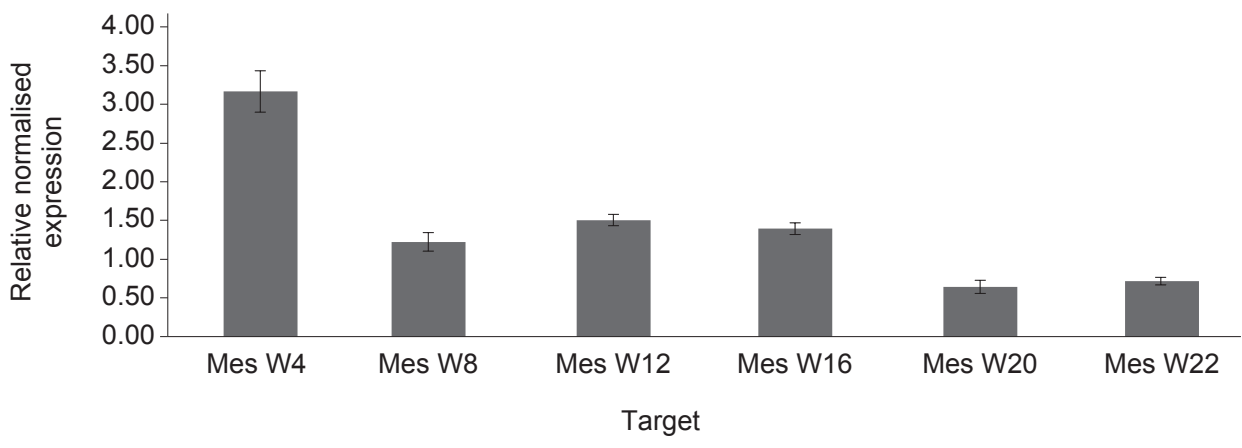

Figure 7. Expression pattern of EgGA2ox6 in different developmental stages of mesocarp tissues. The transcript levels were determined by qRT-PCR. Bars indicate standard error (SE). 


\section{CONCLUSION}

In summary, EgGA2ox6 gene was successfully identified and isolated in oil palm. Motif analysis and MSAs suggested that EgGA2ox6 belongs to the 2-ODD $\mathrm{C}_{19} \mathrm{GA} 2 \mathrm{ox}$ class. Based on expression profile analysis, we can conclude that EgGA2ox6 demonstrated a GA deactivating gene-specific that regulate GA metabolism in oil palm mesocarp. The identification and expression study of EgGA2ox6 would provide fundamental molecular information to further analyse GA metabolic regulation in oil palm, particularly in mesocarp development.

\section{ACKNOWLEDGEMENT}

The authors would like to thank the DirectorGeneral of MPOB for permission to publish this article. We appreciate the help of Dr. Ooi Siew Eng and Lim Fook Hwa for critically reviewing this manuscript. Special thanks to Dr. Faizahani Abdul Rahman for proof read this manuscript. We would also like to acknowledge members of Gene Function Group for their assistance.

\section{REFERENCES}

Azizi, P; Rafii, M Y; Mahmood, M; Abdullah, S N A; Hanafi, M M; Latif, M A; Sahebi, M and Ashkani, S (2017). Evaluation of RNA extraction methods in rice and their application in expression analysis of resistance genes against Magnaporthe oryzae. Biotechnol. Biotechnol. Equip., 31: 75-84.

Busov, V B; Meilan, R; Pearce, D W; Ma, C P; Rood, S B and Strauss, S H (2003). Activation tagging of a dominant gibberellin catabolism gene (GA 2-oxidase) from poplar that regulates tree stature. Plant Physiol., 132: 1283-1291.

Chen, S; Wang, X; Zhang, L; Lin, S; Liu, D; Wang, Q; Cai, S; El-Tanbouly, R; Gan, L; $\mathrm{Wu}, \mathrm{H}$ and $\mathrm{Li}, \mathrm{Y}$ (2016). Identification and characterization of tomato gibberellins 2-oxidase (GA2oxs) and effects of fruit-specific SIGA2ox1 overexpression on fruit and seed growth and development. Hortic. Res., 3: 16059. DOI:10.1038/ hortres.2016.59.

Cowling, R J; Kamiya, Y; Seto, H and Harberd, N P (1998). Gibberellin dose-response regulation of GA4 gene transcript levels in Arabidopsis. Plant Physiol., 4: 1195-1203.

Dijkstra, C; Adams, E; Bhattacharya, A; Page, A F; Anthony, P; Kourmpetli, S; Power, J B; Lowe,
K C; Thomas, S G; Hedden, P; Philips, A L and Davey, M R (2008). Over-expression of a gibberellin 2-oxidase gene from Phaseolus coccineus L. Enhances gibberellin inactivation and induces dwarfism in Solanum species. Plant Cell., 27: 463-470.

Du, Q; Li C; Li, D and Lu, S (2015). Genome-wide analysis, molecular cloning and expression profiling reveal tissue-specifically expressed, feedbackregulated, stress-responsive and alternatively spliced novel genes involved in gibberellin metabolism in Salvia miltiorrhiza. BMC Genomic, 16: 1087-1109.

El-Sharkawy; Kayal, W E; Prasath, D; Fernandez, $\mathrm{H}$; Bouzayen, M; Svircev, A M and Jayasankar, S (2012). Identification and genetic characterization of gibberellin 2-oxidase gene that control tree stature and reproductive growth in plum. J. Exp. Bot., 63: 1225-1239.

Escobar, M D and Hunt, J L (2017). A cost-effective RNA extraction technique from animal cells and tissue using silica columns. J. Biol. Methods, 4: 2. DOI:10.14440/jbm.2017.184.

Fidelibus, M W; Davies, F S and Campbell, C A (2002). Gibberellic acid application timing effects fruit quality of processing oranges. Amer. Soc. for HortSci., 37: 353-357.

Gupta, R and Chakrabarty, S K (2013). Gibberellic acid in plant: Still a mystery unresolved. Plant Signal. Behav., 8: e25504.

Halim, M A A; Azmi, S N and Ramli, Z (2019). Identification of reliable reference genes for gen expression studies of oil palm plantlet using Normfinder and Bestkeeper algorithm. J. Oil Palm Res., 31: 204-211.

Han, F and Zhu, B (2011). Evolutionary analysis of three gibberellin oxidase genesin rice, Arabidopsis and soybean. Gene, 471:1. DOI: 10.1016/j. gene.2010.10.010.

Hedden, P and Thomas, S G (2012). Gibberellin biosynthesis and its regulation. Biochem. J., 444: 1125.

Hu, Y X; Tao, Y B and Xu, Z F (2017). Overexpression of Jatropha Gibberellin 2-oxidase6 (JcGA2ox6) induces $\mathrm{d}$ warfism and smaller leaves, flowers and fruits in Arabidopsis and Jatropha. Front. Plant Sci., 8: 2103. DOI: 10.3389/fpls.2017.02103.

Huang, J; Tang, D; Shen, Y; Qin, B; Hong, L; You, L; You, A; Li, M; Wang, X; Yu, H; Gu, M and Cheng, Z (2010). Activaton of gibberellin 2-oxidase decrease 
active gibberellin level and creates a dominant semi-dwarf phenotype in rice (Oryza sativa L.). J. Genet. Genomics, 37: 23-36.

Huang, Y; Wang, X; Ge, S and Rao, G Y (2015). Divergence and adaptive evolution of the gibberellin oxidase genes in plants. BMC Evol. Biol., 15: 207. DOI: 10.1186 /s12862-015-0490-2.

Imbeaud, S; Graudens, E; Boulanger, V; Barlet, X; Zaborski, P; Eveno, E; Mueller, O; Schroeder, A and Auffray, C (2005). Towards standardization of RNA quality assessment using user-independent classifiers of microcapillary electrophoresis traces. Nucleic Acids Res., 33: 5-56.

Jahn, C E; Charkowski, A O and Willis, D K (2008). Evaluation of isolation methods and RNA integrity for bacterial RNA quantitation. J. Microbiol. Methods, 75: 318-324.

Kawai, Y; Ono, E and Mizutani, M (2014). Evolution and diversity of the 2-oxoglutarate-dependent dioxygenase superfamily in plants. Plant J., 78: 328343.

Lange, M J P; Liebrandt, A; Arnold, L; Chmielewska, S M; Felbberger, A; Freier, E; Heuer, M; Zur, D and Lange, T (2013). Functional characterization of gibberellin oxidases from cucumber Cucumis sativus L. Phytochemistry, 9: 62-69.

Lee, D J and Zeevaart, J A (2005). Molecular cloning of GA2-oxidase from Spinach and its ectopic expression in Nicotiana sylvestris. Plant Physiol., 138: 243-254.

Leige, S and Pfaffl, M W (2006). RNA integrity and the effect on the real-time qRT-PCR performance. Mol. Aspects Med., 27: 126-139.

Lester, D R; Ross, J J; Smith, J J; Elliott, R C and Reid, J B (1999). Gibberellin 2-oxidation and the SLN gene of Pisum sativum. Plant J., 19: 65-73.

Li, H; Wu, H; Qi, Q; Li, H; Li, Z; Chen, S; Ding, Q; Wang, Q; Yan, Z; Gai, Y; Jiang, X; Ding, J; Gu, T; Hou, X; Richard, M; Zhao, Y and Li, Y (2019). Gibberellins play a role in regulating tomato fruit ripening. Plant Cell Physiol., 60: 1619-1629.

Livak, K J and Schmittgen, J D (2001). Analysis of relative gene expression data using real-time quantitative PCR and the 2[-Delta Delta $\left(C_{t}\right)$ ] method. Methods, 25: 402-408.

Lo, S F; Yang, S F; Chen, K T; Hsing, Y I; Zeevaart, J A; Chen, L J and Yu, S M (2008). A novel class of gibberellin 2-oxidases control semi-dwarfism, tillering and root development in rice. Plant Cell., 20: 2603-2618.

Martin, D N; Proebsting, W M and Hedden, P (1999). The SLENDER gene of pea encodes a gibberellins 2-oxidase. Plant Physiol., 121: 775-781.

Nakayama, M; Yamane, H; Murofushi, N; Takahashi, N; Mander, L and Seto, H (1991). Gibberellin biosynthetic pathway and the physiologically active gibberellin in the shoot of Cucumis satious L. J. Plant Growth Regul., 1: 115-119.

Olszewski, N; Sun, T P and Gubler, F (2002). Gibberellin signalling: Biosynthesis, catabolism and response pathways. Plant Cell., 14: 61-80.

Pan, C; Tian, K; Ban, Q; Wang, L; Sun, Q; He, Y; Yang, Y; Pan, Y; Li, Y; Jiang, J and Jiang, C (2017). Genome-wide analysis of the biosynthesis and deactivation of gibberellin-dioxygenases gene family in Camellia sinensis (L.) O. Kuntze. Genes, 8: 235-255.

Quinet, M and Jacquemart, A L (2015). Difference between pollination and parthenocarpy in the 'conference' pear production. Acta Hortic, 1094: 359366.

Rademacher, W (2016). Chemical regulators of Gibberellin status and their application in plant production. Annual Plant Reviews, 49: 359-403.

Rahman, M N H A; Shaharuddin, N A; Wahab, N A; Wahab, P E M; Abdullah, M O; Abdullah, N A P; Parveez, G K A; Roberts, J A and Ramli, Z (2016). Impact of Paclobutrazol on the growth and development of nursery grown clonal oil palm (Elaeis guineensis Jacq.). J. Oil Palm Res., 28: 404414.

Rieu, I; Eriksson, S; Powers, S J; Gong, F; Griffiths, J; Woolley, L; Benlloch, R; Nilson, O; Thomas, S G; Hedden, P and Phillips, A L (2008). Genetic analysis reveals that C19-GA2-oxidation is a major gibberellins inactivation pathway in Arabidopsis. Plant Cell., 20: 2420-2436.

Sakamoto, T; Kobayashi, M; Itoh, H; Tagiri, A; Kayano, T; Tanaka, H; Iwahori, S and Matsuoka, M (2001). Expression of a gibberellin 2-oxidase gene around the shoot apex is related to phase transition in rice. Plant Physiol., 125: 1508-1516.

Salazar-Cerezo, S; Martinez-Montiel, N; GarciaSanchez, J; Perez-Y-Terron, R and MartinezContreras, R D (2018). Gibberellin biosynthesis and metabolism: A convergent route for plants, fungi and bacteria. Microbiol. Res., 208: 85-98. 
Sanchez, E; Tricon, D; Mora R; Quiroz, D; Decroocq, $\mathrm{V}$ and Prieto, H (2017). A fast and efficient protocol for small RNA extraction in Japanese plum and other Prunus species. Electron. J. Biotechnol., 30: 103109.

Sangwiroonthon, K; Sanputawong, S, Preecha, C and Nakorn, S N (2017). Effect of NAA and $\mathrm{GA}_{3}$ at different concentrations on growth and quality of oil palm bunch and fruit (Elaeis guineensis Jacq.). Int. J. Agric. Technol., 13: 2393-2402.

Schomburg, F M; Bizzell, C M; Lee, D J; Zeevaart, J A D and Amasino, R M (2003). Overexpression of a novel class of gibberellin 2-oxidases decreases gibberellins level and creates dwarf plants. Plants Cell., 15: 151-163.

Serrani, J C; Sanjuan, R; Ruiz-Rivero, O; Fos, M and Garcia-Martinez, J L (2007). Gibberellin regulation of fruit set and growth in tomato. Plant Physiol., 145: 246-257.

Shan, C; Mei, Z; Duan, J; Chen, H; Feng, H and Cai, W (2014). OsGA2ox5, a gibberellin metabolism enzyme, is involved in plant growth, the root gravity response and salt stress. PLOS ONE, 9: e87110. DOI: 10.1371/journal.pone.0087110.

Tamura, K; Dudley, J; Nei, M and Kumar, S (2007). MEGA4: Molecular Evolutionary Genetics Analysis (MEGA) software version 4.0. Mol. Biol. Evol., 24: 1596-1599.

Teh, H F; Neoh, B K; Wong, Y C; Kwong, Q B; Ooi, T E K; Ng, T L M; Tiong, S H; Low, J Y S; Danial, A D; Ersad, M A; Kulaveerasingam, $\mathrm{H}$ and Appleton, D R (2014). Hormones, polyamines, and cell wall metabolism during oil palm fruit mesocarp development and ripening. J. Agric. Food Chem., 62: 8143-8153.

Thomas, S G; Phillips, A L and Hedden, P (1999). Molecular cloning and functional expression of gibberellin 2-oxidases, multifunctional enzymes involved in gibberellin deactivation. Proc. Natl. Acad. Sci. USA, 96: 4698-4703.

Transberger, T J; Dussert, S; Joet, T; Argout, X; Summo, M; Champion, A; Cros, D; Omore, A; Nouy, B and Morcillo, F (2011). Regulatory mechanisms underlying oil palm fruit mesocarp maturation, ripening, and functional specialization in lipid and carotenoid metabolism. Plant Physiol., 156: 564-584.

Watanabe, M; Segawa, H; Murakami, M; Segawa, S and Komori, S (2008). Effects of plant growth regulators on fruit set and fruit shape of parthenocarpy apple fruit. J. JPN Soc. Hortic. Sci., 77: 350-357.

Wong, K S and Pang, H M (2013). Simplifying HT RNA quality and quantity analysis. GEN, 33: 17. DOI:10.1089/gen.33.2.09.

Wong, Y C; Teh, H F; Mebus, K; Ooi T E K; Kwong Q B; Koo, K L; Ong, C K; Mayes, S; Chew, K T; Appleton, D R and Kulaveerasingam, H (2017). Differential gene expression at different stages of mesocarp development in high- and low-yielding oil palm. BMC Genom., 18: 470. DOI: 10.1186/s12864017-3855-7.

Wong, Y C; Kwong, Q B; Lee, H L; Ong, C K; Mayes, S; Chew, F T; Appleton, D R and Kulaveerasingam, $H$ (2014). Expression comparison of oil biosynthesis genes in oil palm mesocarp tissues using custom array. Microarray, 3: 263-281.

Wuddineh, W A; Mazarei, M; Zhang, J; Poovaiah, C R; Mann, D G J; Ziebell, A; Sykes, R W; Davis, M F; Udvardi, M K and Jr, C N S (2015). Identification and overexpression of Gibberellin 2-oxidase (GA2ox) in switchgrass (Panicum virgatum L.) for improved plant architecture and reduced biomass recalcitrance. Plant Biotechnol. J., 13: 636-647.

$\mathrm{Xu}, \mathrm{J}$; Lange, $\mathrm{T}$ and Altpeter, F (2002). Cloning and characterization of a cDNA encoding a multifunctional gibberellin 20-oxidase from perennial ryegrass (Lolium perenne L.). Plant Sci., 163: 147-155.

Xu, Y L; Li, L; Wu, K; Peeters, A J; Gage, D A and Zeevaart, J A (1995). The GA5 locus of Arabidopsis thaliana encodes a multifunctional gibberellin 20-oxidase: molecular cloning and functional expression. Proc. Natl. Acad. Sci. USA, 92: 66406644.

Yamaguchi, S (2008). Gibberellin metabolism and its regulation. Annu. Rev. Plant Biol., 59: 225-251.

Yeap, W C; Loo, J; Wong, Y and Kulaveerasingam, $H$ (2014). Evaluation of suitable reference genes for qRT-PCR gene expression normalization in reproductive, vegetative tissues and during fruit development in oil palm. Plant Cell Tissue Organ Cult., 116: 55-66.

Zhang, C and Whiting, M (2013). Plant growth regulators improve sweet cherry fruit quality without reducing endocarp growth. Sci. Hortic., 150: 73-79.

Zhang, Q; Rao, X; Zhang, L; He, C; Yang, F and Zhu, S (2016). Mechanism of internal browning of 
pineapple: The role of gibberellins catabolism gene (AcGa2ox) and GAs. Sci. Rep., 6: 33344. DOI: 10.1038/ srep33344.

Zhou, B; Lin, J Z; Peng, W S; Peng, D; Zhuo, Y H; Zhu, D F; Huang, X; Tang, D; Guo, M; He, R; Zhang, J; Li, X; Zhao, X and Liu, X (2012). Dwarfism in Brassica napus L. induced by the over-expression of a gibberellin 2-oxidase gene from Arabidopsis thaliana. Mol. Breed., 29: 115-127.

Zulkifli, Y; Norziha, A; Naqiudin, M H; Fadila, A M; Nor Azwani, A B; Suzana, M; Samsul, K R; Ong-Abdullah, M; Singh, R; Ghulam Kadir Ahmad Parveez and Kushairi, A (2017). Designing the oil palm of the future. J. Oil Palm Res., 29: 440-455.

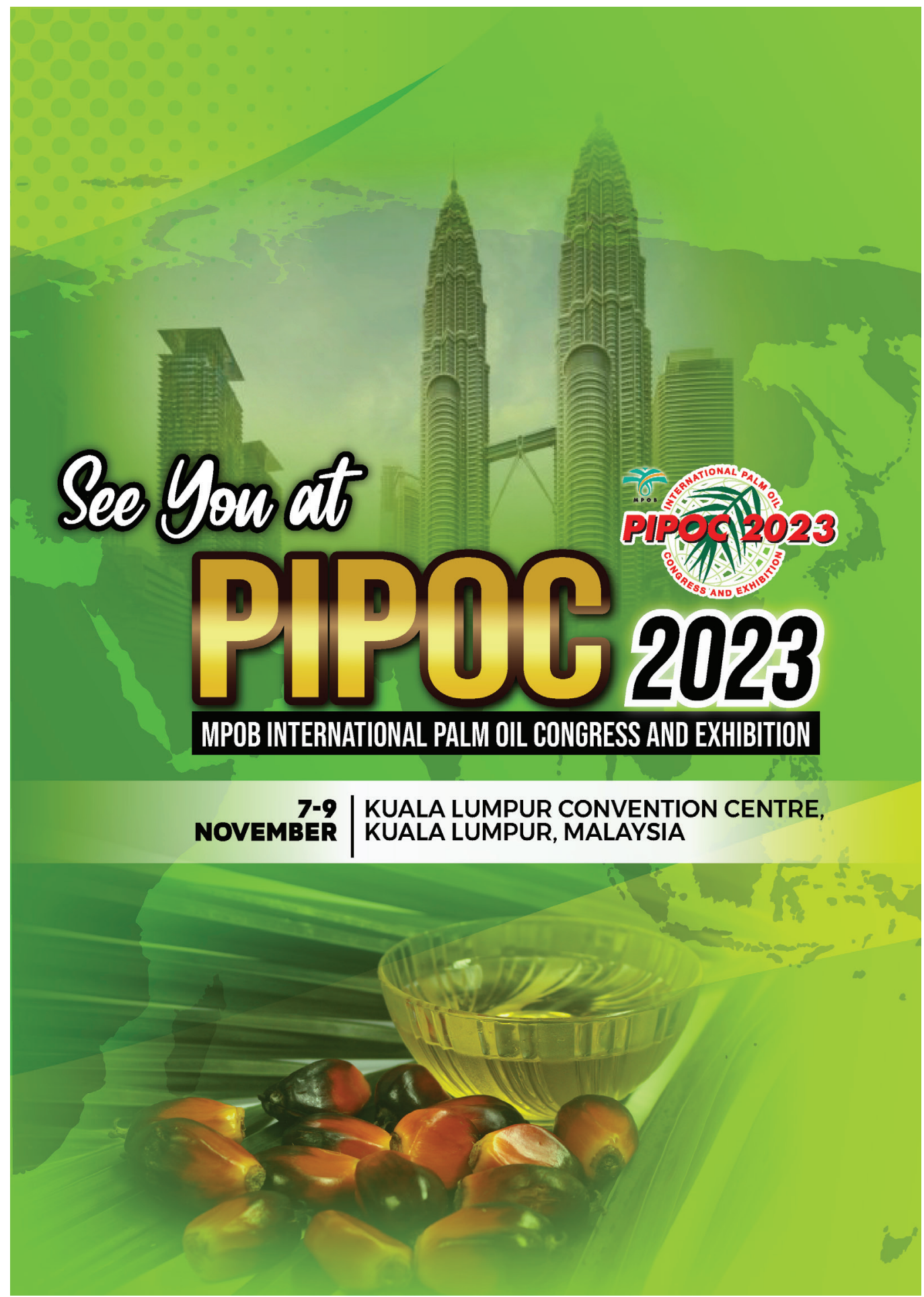

